\title{
Monsignor Ivan Illich's Critique of the Institutional Church, I960- 1966
}

\author{
by ROSA BRUNO-JOFRÉ and JON IGELMO ZALDÍVAR \\ Queen's University, Kingston, Ontario \\ Universidad de Deusto \\ E-mails:brunojor@queensu.ca \\ jigelmoza@deusto.es
}

This paper examines the process of radicalisation of Monsignor Ivan Illich during the I96os, having as its setting Cuernavaca, Mexico - a creative, fluid space where Illich was in contact with Bishop Méndez Arceo, Erich Fromm and Gregorio Lemercier. Illich's writings and the reports from the centres led by him are placed here in context, and it is argued that his encounter with psychoanalysis in Cuernavaca shaped his critique of the Church as an institution. The radicalisation of his concept of the Church reached a high point with the publication of 'The seamy side of charity' and 'The vanishing clergyman', both in 1967.

$\neg$ his paper examines the process of radicalisation of Monsignor Ivan Illich (1926-2002), leader of a network of centres including the C Center for Intercultural Formation (1960-7) based at Fordham University, New York; the Centre of Cultural Research (Centro de Investigaciones Culturales, 1961-6), which was a residence for prospective missionaries; and the Centre for Intercultural Documentation (Centro Intercultural de Documentación, 1963-76). Both CIC and CIDOC were based in Cuernavaca, Mexico. ${ }^{1}$

$\mathrm{CIC}=$ Centre of Cultural Research $/$ Centro de Investigaciones Culturales; CIDOC $=$ Centre for Intercultural Documentation/Centro Intercultural de Documentación; CIF $=$ Center for Intercultural Formation; CIFR $=$ CIF Reports; NCWC $=$ National Catholic Welfare Council; PAVLA = Papal Volunteer for Latin America

${ }^{1}$ The CIC counterpart in Brazil, located first in Anápolis (1961-2) and later in Petrópolis (1962-6), was the Centro de Formaçao Intercultural (Centre of Intercultural Formation/CENFI). In 1963 the Centro Intercultural de 
At the time of the creation of CIF and CIC, Illich was thirty-four years old. He had been ordained priest in Rome in $195^{\circ}$. By then he had completed master's degrees in philosophy and theology at the Gregorian University in Rome, and had obtained a PhD in the philosophy of history from the University of Salzburg. Early in the 1950s he moved to New York to continue his academic career: the focus of his research was Albertus Magnus (1206-8o). Once in New York, he devoted himself to work with the Puerto Rican community and later went to Puerto Rico. The development and radicalisation of his thinking in the 1960 os was closely related to his lived experience in Cuernavaca, which is fundamental to any understanding of his thought and the work on education, health and transportation that he carried on until his death in 2002. This article in part responds to Charles Taylor's observation that 'It is an understatement to say that those who have read the books for which Illich is best known, even those most enthused by them, have rarely seen into the rich and complex position which underlies them. But this position is extraordinarily fertile and illuminating.' 2

It is argued that Illich started the programme in Cuernavaca with a personal vision of missionary work, although he did not reject either the 'Papal Volunteer for Latin America' (PAVLA) initiative, a lay apostolate programme approved by the Pontifical Commission for Latin America on 19 May 196o, or the simple practice of sending missioners in accord with John XxIII's appeal to religious congregations of 1961. Both initiatives were in line with the process of modernisation in Latin America led by the United States in response to the Cuban revolution. Illich's centres prepared missioners until 1967: between 1961 and 1965 , a total of 408 missioners attended the sessions offered by CIC in Cuernavaca, of whom 130 came from Canada, 240 from the United States and twenty-eight from Europe. 3

Illich developed the practice of missioners embedding themselves in their target culture rather than being agents of their own culture; this is what he called missionary poverty. It was grounded in his pastoral experience in Puerto Rico and New York in the 1950s and informed by the early influence of Jacques Maritain and neo-Thomism, in particular Maritain's personalism, which placed the human being at the centre of Catholic thought. The questioning of modernity and notions of progress,

Documentación (Centre for Intercultural Documentation/CIDOC) was started within CIC. In 1966 the network of centres moved from Hotel Chulavista to Rancho Tetela, on the outskirts of Cuernavaca. CIDOC became the only functioning centre, but it did not offer residence to missioners.

${ }^{2}$ C. Taylor, 'Foreword', to David Cayley and Ivan Illich (eds), The rivers north of the future: the testament of Ivan Illich as told to David Cayley. Toronto 2005, p. ix.

3 Attendance information for the CENFI in Petrópolis is not available. 
as well as of American efforts to bring modernisation to Latin America, characterised Illich's approach. At the time it was already acknowledged that any approach which could be defined as springing from 'colonialism' was impossible, but Illich's distrust of modernisation, his emphasis on people experiencing faith through their own culture, and his idea that 'corrupted Christianity gives rise to the modern' set his view apart. 4

In this paper it is argued that there was a process of radicalisation in Illich's approach to mission and in the work of the Centres that becomes structurally evident in 1964. Moreover Illich's encounter with psychoanalysis in Cuernavaca shaped one important facet of his critique of the Church as an institution. The radicalisation of his thought regarding the Church reached a high point in 1967 with the publication of 'The seamy side of charity' 5 and 'The vanishing clergyman', which led to his being called to Rome for questioning by the Congregation for the Doctrine of the Faith on 17 June 1968. After that Illich distanced himself from the Church.

Illich became a public intellectual who questioned the institutionalised Church and American imperialism, but did not provide a blue-print for society or a response to issues as did liberation theologians in the late 1960 and 1970 . Illich opened up spaces for liberation theology in his centres, but was not in sympathy with its strong modernist components and elements of Marxian analysis. Most important, as Daniel Berrigan said with regard to Illich's presence in Latin America, 'this was an early instance of Catholic theologians questioning whether the special conditions of Latin America might call for its own theology'. ${ }^{6}$

Quentin Skinner's notion that 'the text in itself is shown to be insufficient as the object of our inquiry and understanding' is essential to this analysis.7 The aim is 'to place the text in its practical context - the problematic political activity or "relevant characteristics" of the society that the authors address and to which the text reponds' ${ }^{8}$ In this case, Illich's text and work is placed in the context of Cuernavaca and Latin America. Furthermore, an analysis of intentionality ('illocutionary force') is as important to the understanding of the text as is its meaning, because it is a 'force-coordinate' with the actual words.9 Inspired by Pierre Bourdieu's notion of 'field', Cuernavaca and its dynamics are approached as a locus with a

4 C. Taylor, A secular age, Cambridge, MA 2007, 740.

5 I. Illich, 'The seamy side of charity', America, 21 Jan. 1967, 88-91.

6 This is quoted from M. I. Bochenski, Transforming faith communities: a comparative study of radical Christianity in sixteenth-century Anabaptism and late twentieth-century Latin America, Eugene, OR 2013, 36

7 Q. R. D. Skinner, 'Meaning and understanding in the history of ideas', History and Theory vii (1969), $3-53$ at p. 35 .

8 J. Tully, Meaning and context: Quentin Skinner and his critics, Cambridge 1988, 10.

9 Skinner, 'Meaning and understanding', $4^{6 .}$ 
history, an internal logic and spiritual and socio-political positionings. ${ }^{\circ}$ These positionings contained interwoven, conflicting readings of what was happening in Latin America and were related to dissatisfaction with the dominant order.

There are a number of key questions: what were the intentions and coordinating forces ('illocutionary forces') that sustained Illich's radicalisation from the late 195 os until the Vatican intervened in 1968? What kind of radicalisation are we talking about? How is Illich's radicalisation related to psychoanalysis? How was he involved with psychoanalysis? In order to fully understand Illich's process of radicalisation and the writings connected with it, it is important to consider the place of psychoanalysis in his life and thought, in particular through his relationship in Cuernavaca with Bishop Sergio Méndez Arceo, Eric Fromm and Gregorio Lemercier.

\section{Cuernavaca in the I96os}

Ivan Illich had brought a neo-Thomistic framework to his pastoral work in New York between $195^{1}$ and $195^{6}$. He had acquired this through his formation with Jacques Maritain in Rome in the 1940s and later at Princeton in 1951. Illich said in interviews conducted in the late 1980 os that he had found in Thomas Aquinas 'the architecture which has made me intellectually free to move between Hugh of St Victor and Kant, between Schutz - or God knows what strange German - and Freud, or, again, into the world of Islam, without getting dispersed'. ${ }^{11}$ NeoThomism, a return directly to the source, St Thomas's writings, is reflected in his understanding of the missioners' process of formation. The missioner would be part of a process of awareness that started with herself.

The missioner develops her natural inclinations, including an inner disposition to the common good, by looking deep within herself, but natural inclinations are subject to corruption given our sinful nature. The missioner, under the influence of new experiences and knowledge, would be led towards principles such as the unity of being, which become relevant when working in missions, in particular in the light of Illich's reservations about the tendency to transplant instead of working toward the development of a rooted, living Church. In Illich's thought, as in Maritain's, there seems to be an overall belief that the human person is ascribed a natural purpose, to be achieved through politics, with acts of virtue directed towards the common good, and a supernatural purpose, to be achieved

${ }^{10}$ P. Bourdieu, Language and symbolic power, ed. J. B. Thompson, trans. G. Raymond and M. Adamson, Cambridge, MA, 1991 .

${ }^{11}$ D. Cayley, Ivan Illich in conversation, Toronto 1992, $15^{\circ}$. 
through religion and ethics. ${ }^{12}$ Illich worked with a theology of reality based on a historical-critical exegesis that would lead to his approach to mission and a profound respect for the uniqueness of a living faith in differing cultural contexts.

Between $195^{1}$ and $195^{6}$ Illich's work with newly-arrived Puerto Ricans in the parish of the Incarnation in New York motivated him to learn Spanish and to gain a knowledge of Puerto Rican culture. This experience, and his notion that it was important to minister to people in a spiritual and religious style of which they could make sense, are important points of reference in attempting to understand his notion of missionary work. When he went to Puerto Rico in November $195^{6}$, as vice-rector of the Pontificia Universidad Católica de Puerto Rico ${ }^{13}$ in Ponce (1956-6o), one of Illich's first steps was to establish the Institute of Intercultural Communication. As J. P. Fitzpatrick wrote, 'the training at the Institute was designed to help the mainland clergy and religious - most of them from middle-class Irish, German or Italian backgrounds - to appreciate the Puerto Ricans for what they are, to form them spiritually and religiously in accordance with their own deep religious values and sentiments, rather than remake them on the American religious pattern'. ${ }^{14}$

In 1960, when Illich left Puerto Rico and his position as vice-rector, Fordham University welcomed him back. At that point, the PAVLA programme was starting up, and within a year John XxIII would launch his appeal to religious orders to send members of their congregations to Latin America. The idea of training missioners appealed to Illich, as well as to the president of Fordham University, Laurence McGinley. ${ }^{15}$ Fordham was asked by the Maryknoll John Considine to back the creation of a centre. Fordham appointed Ivan Illich as executive director of CIF for a period of five years and provided institutional support. Initially, Illich's creation of the CIF and its publications were fully supported by the Latin American Bureau of the National Catholic Welfare Council (NCWC) of which Considine was the director. The Bureau provided Illich with $\$ 75$,ooo to initiate the project. ${ }^{16}$

The decision to open CIC in Cuernavaca was made during a visit made by Illich to that city and after his meeting with Bishop Méndez Arceo. The first missioners arrived, and courses started, in 1961. Meanwhile CIF remained in New York, serving as an administrative base. Once in Cuernavaca, Illich

\footnotetext{
${ }^{12}$ J. Mettepenningen, Nouvelle Théologie, new theology: inheritor of modernism, precursor of Vatican II, New York 2010, 26.

${ }^{13}$ See J. Fitzpatrick, The stranger is our own: reflections on the journey of Puerto Rican migrants, Kansas City, Mo 1996, 22.

${ }_{14}$ J. P. Fitzpatrick, 'What is he getting at?', America, 25 Mar. 1967, 444.

15 M.J. O'Meagher, 'Catholicism, reform and development in Latin America, 1959-67', unpubl. PhD diss. Duke 1994, 372.

16 Ibid. 377 .
} 
and his team ${ }^{17}$ began to respond to a range of changes in the Church and in Latin America which had taken place in the late $195^{\circ}$ os and the 1960 . This included the return from Europe, in particular from Louvain, of Latin American clergy who had become familiar with innovative theological currents which were opening up new avenues in social Catholicism. It also involved the dissemination of the writings of Jacques Maritain, Henri de Lubac, the French Dominican priest Yves Congar, and the German Jesuit Karl Rahner, all of whom had worked on ways in which the Church should engage with the world and were critical of the social function of the Church. Social Catholicism had taken on a new configuration, as expressed in programmes in Latin America and in the development of Christian Democratic parties. Reading Vatican II through Latin American experience opened a window that legitimised theological thinking rooted in a Latin American reality, which ultimately took shape in liberation theology. From its early beginnings, liberation theology would influence what was happened in Cuernavaca.

The historically complacent relationship between a benevolent United States and Latin America, cultivated by foreign missioners, particularly Americans, after the Second World War, had been shaken. The Maryknolls provided an example during this period. They distanced their mission from the USA while trying to live the ideal of an emerging Catholic Church, responding to Vatican II, the advent of liberation theology, social movements in the USA in the 1960 s and a new generation of missionaries seeking alternatives. The emphasis was on spirituality rather than on economic aid from the North. ${ }^{18}$ The Cuban revolution in 1959 -in particular its grassroots character-generated sympathy in Latin America and a strong US reaction. Thus, in Latin America, the Cold War acquired a new discursive component.

However, in Latin America there were not only movements of social action supported by sectors of the Catholic clergy, often with a grassroots character, but also early steps towards a convergence of Christianity and Marxism by 'selected affinity' in the early 1960 , particularly in Brazil. ${ }^{19}$ At the same time, conservative sectors of the Church, especially in the USA, were concerned about Communism and also with the advance of Protestantism in Latin America. ${ }^{20}$ The launch of the Alliance for

17 The first team included Encarnación Armas, Gerald Morris, William McKeon, Betsie Hollants, John Vogel and Feodora Stancioff: CIF, The CIF session June I 8th to October 9th, I961, folder 370.196 C397, Daniel Cosío Villegas Library, Colegio de México, Mexico City.

${ }^{18}$ S. Fitzpatrick-Behrens, The Maryknoll Catholic mission in Peru, I943-1989, Notre Dame, In $2012,15^{2-3}$.

19 M. Löwy and C. Pompan, 'Marxism and Christianity in Latin America', Latin American Perspectives xx (1993), 28-42.

${ }^{20}$ Ibid. 
Progress on 17 August $19^{61^{21}}$ by John F. Kennedy, as an expression of a modernising vision to transform Latin America and contain Communism, ${ }^{22}$ was paralleled by the call from John XxIII on the same day to send missionaries and lay volunteers to Latin America. ${ }^{23}$ Previously, on 15 May 1961, John xxiII had issued the encyclical Mater et Magistra in which he addressed the social question in light of Catholic doctrine. This document was infused with ideas of progress: it referred to the difference between developed and underdeveloped countries, and those on the way to development (Harry Truman's concepts); made reference to inequality between individuals and nations; and expressed the need for an adequate agrarian policy based on the redistribution of land. ${ }^{24}$ Such concepts were central to the Christian Democratic Party in Chile which relied on community development and claimed that both capitalism and socialism could be transcended in a communitarian society. In the end, however, that party developed along capitalist lines.

At the time, there was a complex political landscape that would move rapidly towards radicalisation. In response a series of coups d'état brought the military to power: in Brazil in 1964, Bolivia in 1964, Panama in 1968, Uruguay in 1973, Chile in 1973 and Argentina in 1976. The creation of repressive states was accompanied by neo-liberal market policies.

Starting work in Cuernavaca, Illich hovered around or inserted himself into the interlocking configurations described; they formed a conceptual space, a field, in which Illich developed the relationships, practices and meanings that were explicit in his writing. In Cuernavaca, Illich encountered the powerful presence of Bishop Sergio Méndez Arceo, who had a transformative and renewed vision of the role of the Church quite different from official church positions and from that of John Considine and the Latin American Bureau of the NCWC. Considine had been the architect of a Catholic plan for Latin America, and it is said that he had the ear of the pope. The Bureau was also fully aligned with Cardinal Richard Cushing of Boston, who had presided over the First Episcopal Inter-

21 Inter-American Economic and Social Council (1961), 'The charter of Punta Del Este: Alliance for Progress: official documents', appendix to J. F. Taffet, Foreign aid as foreign policy: the Alliance for Progress in Latin America, New York 2007, 205-23.

${ }^{22}$ M. T. Berger, "Toward our common American destiny": hemispheric history and pan-American politics in the twentieth century', Journal of Iberian and Latin American Research viii (2002), 57-88; Taffet, Foreign aid as foreign policy; M. E. McCammon, Kennedy and Latin America, Lanham, MD-New York-London 1994.

23 A. Casaroli, 'Appeal of the Pontifical Commission to North American superiors', in G. M. Costello (ed.), Mission to Latin America: the successes and failures of a twentiethcentury crusade, Maryknoll, NY 1979, appendix at pp. 273-81.

${ }^{24} \mathrm{~J}$. Comblin, 'La Iglesia latinaomericana desde el Vaticano II', in La Tercera Confrencia del CELAM (i) (Documentación Politica vii), Montreal 1978, 1 19-24, reproduced from Contacto X xv (Feb. 1978). 
American Conference on 2-4 November 1959, convoked by the Holy See at Georgetown University. Cushing, a personal friend of the Kennedys, was profoundly concerned with Communism, committed to the Alliance for Progress, and engaged with the discourse of the Cold War. ${ }^{25}$

Cuernavaca moved not only towards a social and cultural aggiornamento, but also towards an aggiomamento where disciplines and fields such as psychology, as well as psychiatry and the place of psychoanalysis, the social sciences, and the arts were developed. Artistic innovation included architecture and a renewed aesthetic sense. This is evident in the renovation of Cuernavaca Cathedral which started in $1956 .{ }^{26}$ Erich Fromm, a social psychoanalyst, who was at one point involved with the Frankfurt school, was living in Cuernavaca and became a neighbour and close friend of Illich. ${ }^{27} \mathrm{He}$ wrote introductions to Illich's work and contributed to CIDOC Informa. ${ }^{28}$

Fromm questioned the philosophical frame of reference of Freud's original theories, in particular the mechanistic materialism current among natural scientists at the beginning of the twentieth century. Instead, Fromm claimed that further development of Freud's thought required dialectical humanism as a frame of reference. By opening up Freud's discoveries (the Oedipus complex, narcissism and the death instinct) and framing them within humanism, they would become more meaningful. ${ }^{29}$ This would imply a 'blend of relentless criticism, uncompromising realism, and rational faith'. $3^{\circ}$

Illich also became very close to Gregorio Lemercier, who was the prior of the monastery of Santa María de la Resurrección, a Benedictine house in Santa María de Ahuacatitlán, and a friend of Bishop Méndez Arceo..$^{1}$ The monastery's involvement in the social services (health, food distribution and spiritual help) and its participation in social struggles along with Méndez Arceo raised new questions among its members. In retrospect, as Alejandro Chao Barona, a former monk, recalls, many of the

${ }^{25}$ J. F. Garneau, 'The first inter-American episcopal conference, November 2-4, 1959: Canada and the United States called to the rescue of Latin America', Catholic Historical Review lxxxvii (2001), 662-87.

${ }^{26}$ See B. López (comp.), Cuernavaca: fuentes para el estudio de una diócesis (CIDOC dossier xxxi), ii, Cuernavaca 1968, 4/468-5/16; M. C. Turrent, 'El sentido de los murales de la Catedral de Cuernavaca', Inventio iii (2006), $5^{-10 .}$

${ }^{27}$ L.J. Friedman, The lives of Erich Fromm: love's prophet, New York 2013, 294.

${ }_{28}$ CIDOC Informa was published between April 1964 and June 1970. Initially it reproduced the same material as that in CIF Reports but in their original language. It also published documents that were used in the preparation of the CIF Reports.

${ }^{29}$ E. Fromm, The heart of man: its genius for good and evil, New York 1964, 14-15.

$3^{\circ}$ Ibid. 15 .

${ }^{31}$ See L. Gutiérrez Quintanilla, Los volcanes de Cuernavaca: Sergio Méndez Arceo, Gregorio Lemecier, Ivan Illich, Cuernavaca 2007, 64 . 
monks were not in a good mental state: the demons were not external, but their own - their own passions, strivings and concerns..$^{3^{2}}$ Lemercier had a hallucination in October 1960 and started rigorous psychoanalytic therapy with Gustavo Quevedo. In June 1961 Lemercier extended the opportunity for such therapy to members of the monastery who became involved in group therapy; the therapists included an Argentinian, Fryda Zmud. 33 Chao Barona referred to the process of therapy as conscientisation: 'we were searching a clear consciousness of our spirituality'. ${ }^{4}$ The Vatican rejected the use of psychoanalysis and in 1965 began proceedings against the monastery, which closed in 1967.35

Méndez Arceo took Lemercier with him to Rome during the sessions of Vatican II. During the fourth period of the council, in September 1965, when Schema 13 on the Church in the modern world was discussed, Méndez Arceo made an appeal for psychoanalysis to be considered as relevant as the work of Darwin or Galileo. In his view, psychoanalysis could be used to 'purify vocations'. ${ }^{6}$ He spoke on behalf of ten Latin American bishops. He was not successful.

Méndez Arceo was concerned that a purely sociological approach was taken when discussing Schema 13, and the anthropological perspective disregarded. He thought that modern human beings were more self-aware, self-conscious ('consciente de sí mismo'), more associable, and tended to rationalise their position vis-à-vis the Absolute. He considered that, during the discussion, atheism was not well addressed. Members of the council did not realise, in Méndez Arceo's view, that it is the positioning of the human being in relation to the Absolute that often leads to atheism. With psychoanalysis, human beings become aware of themselves. He then wrote that 'psychoanalysis is irreversibly in the discourse of the humane. It is a true science in modern sense'. He went on to say that 'with psychoanalysis, human beings do not move to mistrust but to dialogue'.37 The question of psychoanalysis and the preoccupation with

$3^{2}$ Ibid. 66.

33 J. A. Litmanovich, 'Las operaciones psicoanalíticas gestadas al interior del monasterio Benedictino de Ahuacatlitlán, Cuernavaca, Morelos, Mexico (1961-1964)', unpubl. PhD diss. Universidad Iberoamericana de Mexico 2008.

34 Gutiérrez Quintanilla, Los volcanes de Cuernavaca, 66.

35 See H. Giniger, 'A monastery in Mexico closed in dispute over psychoanalysis', New York Times, 6 Sept. 1967, 15 .

${ }^{6}{ }^{6}$ S. Méndez Arceo, 'Intervención conciliar, algunas observaciones al Esquema XIII', in López, Fuentes para el estudio de una diócesis, i, 4/154-8. The full text of Méndez Arceo's presentation is reproduced in Latin as it was written.

37 'Méndez Arceo habla al fin', ibid. 4/188-95 at p. 193. The article was reproduced from SIEMPRE, Cuernavaca (27 Mar. 1966), 8, 9. See 'Mexican bishop endorses Freud: ecumenical council is told Catholic Church should back psychoanalysis', New York Times, 29 Sept. $196_{5}, 1$, column 4 . 
neurotic personalities and affective imbalances among religious were not unique to Cuernavaca. ${ }^{8}$

Illich's centres served as spaces for the discussion of emergent ideas in Latin America. A case in point is the quite informal meeting that was held in 1964, in Petrópolis, Brazil, at the CENFI facility, which was the counterpart to the CIC in Cuernavaca for missioners working in Brazil. Illich gathered together a group of intellectuals, including Gustavo Gutiérrez, Juan Luis Segundo, Segundo Galilea and Lucio Gera, who met to search for the meaning of Christianity in the context of poverty and oppression in Latin America. Gutiérrez presented a paper in which theology was introduced as 'critical reflection on praxis'. The original thinking behind liberation theology was also discussed. 39

Cuernavaca was the right place for Illich. It had been a field of Catholic experimentation before Vatican II, under the leadership of Bishop Méndez Arceo. In the 195 os, for example, Méndez Arceo had started to renovate the cathedral by having it stripped of its Baroque altar, nineteenthcentury ornaments, and statues, leaving a lone statue of the Virgin Mary. The restored cathedral manifested a severe Franciscan elegance, retaining portions of the original basilica's rough walls and original seventeenthcentury frescos depicting the martyrdom of St Phillip de Jésus, missionary priest and Mexican saint. The modernism of the cathedral became a matter of scandal, as was the distribution of Bibles in Spanish, the authorisation of the use of psychoanalysis at Santa María de la Resurrección, $4^{\circ}$ the reform to the liturgy including the use of vernacular and the incorporation of popular music into church services. Cuernavaca was unique. ${ }^{4^{1}}$ It was a special space in which the local Church as an institution had attempted to engage with the spirit of the times and with the people themselves, even before Vatican II. Meanwhile, Latin American and foreign theologians were constructing a way to relate to God from a Latin American stand-point, with its poverty, pain, dependency and injustice.

Illich's centres in Cuernavaca quickly became fluid spaces where a new logic - a challenging way of making sense of reality - generated a field (à la Bourdieu), or conceptual space of social positionings. Illich cannot be identified with any of these positionings, but emerged as a critical voice on his own terms. The CIF Reports between 1964 and 1967 can be

$3^{8}$ See Luis Bravo Valdivieso (Santiago, Chile) to Monseñor Sergio Méndez Arceo (Vatican Council, Rome), 12 Nov. 1965, in López, Fuentes para el estudio de una diócesis, ii, 4/273-5.

39 C. Smith, The emergence of liberation theology, Chicago 1991, 120.

$4^{\mathrm{O}}$ R. du Plessix Gray, Divine disobedience: profiles in Catholic radicalism, New York 1970, 259-6o.

$4^{1}$ 'Cuernavaca was the original home of the mariachi mass': R. S. MacKin, 'Becoming the red bishop of Cuernavaca: rethinking Gill's religious competition model', Sociology of Religion lxiv (Winter 2003), 499-514 at p. $5^{\text {o6. }}$ 
construed as the material expression of Cuernavaca's field, reaching out to Latin America and other places in the world. In these volumes its configurations and Illich's process of radicalisation can be traced. $4^{2}$

\section{Religious vocation, the Center for Intercultural Formation, and the break with the official North}

Between 1962 and 1964 the CIF Reports introduced Illich's notions of the missioner. These were rooted in the Gospel and demonstrated a preoccupation with authenticity, self-awareness and motivation, underpinned by the influence of psychoanalysis. 43 However, from the start, the Reports were seen as oriented politically toward a critique of the North although, by and large, the texts used were quite conventional. Thus, there are interesting defensive statements such as

CIF Reports is a service with a political platform. Our politics - let us be frank - is to get you involved [in] Latin America. We do not wish to shout with certain extremist groups in either North or Latin America. We only say that we are here, ready to report to you the thinking and activities that have been and are being generated by certain Christian revolutionaries in the Americas. 44

In February 1964 Illich took on the role of editor of the Reports and announced a change. Until then it had published materials for the missionary seminars and collections of articles on Latin America supporting specific themes. After spending two days discussing the future of the Reports, the team decided, in Illich's words, that a change was necessary in order to provide what CIF had and wanted to share with its audience. The Reports became the medium for articles on Latin America. From the start, they reached an audience (religious and lay) well beyond CIF's seminars. When announcing the change, Illich wrote that 'CIF is growing rapidly. Two years ago most of our effort went into training personnel for Latin America. Today, formation is one part of an enriched expanded program which emphasises research and documentation.' 45 The Board, which had included John Considine, was disbanded and an editorial committee established consisting of Illich and his trusted

$4^{2}$ The CIF Reports were compiled by CIDOC in the collection CIDOC Cuaderno and published in 1969 in six volumes (xxxvi-xli).

43 See, for example, I. Illich, 'A letter to Mary', CIFR i (Apr. 1962), repr. in CIDOC, CIF Reports, I: April I962-March 1963 (CIDOC Cuaderno xxxvi, 1969), 1/51-2.

44 P. V. Brison, 'Notes from the editor', CIFR i (Jan. 1963), repr. ibid. 8/5.

45 I. Illich, 'A note from the publisher', CIFR ii (Mar. 1964), repr. in CIDOC, CIF Reports, II: April I963-March I964 (CIDOC Cuaderno xxxvii, 1969), 10/3-10/4. 
employees and friends, Valentina Borreman, director of CIDOC, and Benjamín Ortega. $4^{6}$

After 1964 the articles in the Reports constituted an eclectic kaleidoscope of alternative grassroots radicalised experiences and political reflections, which were at odds with the notions of change that had been sustained by sectors of the hierarchy of the Church, particularly by Archbishop Cushing, the NCWC's Latin American Bureau and US policy-makers. At the core of that discourse and practice had been the modernisation of Latin America, in accord with American policies, which included degrees of reform (for example, agrarian reform and the militarisation of the region).

The change of direction came from the South itself, although many foreign members of the Church became active agents. It was part of the lived experience, the reception of Vatican II, the critique of American policies emerging from missionary work in the field-such as the case of the Maryknolls from the late 1960 - and the intensity of social and political movements in Latin America. There was a movement from South to North, in terms of alternative visions of the role of the Church in Latin America.

The change of political direction after 1964 becomes clear when the origin and tenor of the articles reprinted in CIF Reports is examined. Between 1964 and 1967 , a concern to report what was happening at the grassroots level in Latin America is evident, as well as a preoccupation with the political movements that were taking shape, such as the growing influence of the Christian Democratic Party in Chile. Thus, there are articles by Marina Bandeira, executive director of the radio school system of the bishops of Brazil and secretary of the Movement for Grassroots Education (MEB); Helder Camara, archbishop of Olinda and Recife, and outspoken representative of liberation theology; Francisco Juliao, peasant leader and representative of the MEB; Carlos Fuentes, Mexican writer; the Berkeley sociologist Ivan Vallier; the Mexican writer, Jose Maria Sbert; Salvador Allende, who would become the first Socialist president of Chile; and Eduardo Frei, who went on to be the Christian Democrat president of Chile. The Reports also printed Adolfo Gilly's 'Camilo Torres: his program', which had first been published in the Montevidean publication MARCHA; Eduardo Galeano's 'Che Guevara: his commitment', reproduced from the Monthly Review, a journal of the New Left; Vicente Lombardo Toledano's 'Marxism and the sacred texts: three sermons', taken from SIEMPRE (Mexico); and Gregorio Lemercier's 'A Benedictine monastery and psychoanalysis', reproduced from Le Monde.

$4^{6}$ Ortega worked on editions of collections published by CIDOC between 1963 and 1976. Valentina Borreman applied for the position at CIDOC by responding to an advertisement in New York. She assumed the direction of CIDOC without previous experience in a documentation centre. Neither one of them was an active member of the Church. 
From 1966 until June 1967 CIDOC was the only centre, located in Rancho Tetela, where the CIF Reports were published. The analysis developed at the centre was two-fold. On the one hand, it disseminated a strong critique of American imperialism, ideas and activities carried on by radical grassroots groups, as well as more moderate reformist approaches such as the one taken by the Christian Democratic Party in Chile. On the other hand, the critique of the Church was relentless. Both elements converged in 'The seamy side of charity', while the critique of the institutionalisation of the Church was expounded in 'The vanishing clergyman'. These publications did not surprise those who knew of the activities of the centre and its radical discourse on vocations.

A related event that had consequences for the relationship between Illich and the Holy See was the intensive summer course (from 11 July to 19 August 1966), organised by the Oficio Catequístico de la Arquidiócesis de Mexico for women and men religious as well as the public. The Equipo de Pastoral de la Unión de Mutua Ayuda Episcopal (Pastoral Team of the Episcopal Union of Mutual Aid/UMAE) and the Centre of Pastoral Research (CIP), a centre related to CIF, were in charge of it. Presentations by members of CIF conveyed statements, mostly dealing with religious vocation, by using aggressive analogies and metaphors, which referred to the search for purity in vocations and the need to remove masks. The latter often took, in their view, the form of religious practices. The following are examples, some of which are not without a patriarchal construction of womanhood and spirituality:

'The vows of religious life destroy the personality and form abnormal human beings': 47 L. Hoinacki $4^{8}$

'The vote of chastity is invalid without the experience of love':49 L. Hoinacki

'The community life of religious communities destroys the personality':50

L. Hoinacki

'Without loving experiences it is impossible to carry out a mature religious life. These experiences are necessary before entering Religion for a conscious

47 Oficio Catequístico Arquidiocesano, 'Informe que su director, Mons. Francisco Aguilera envía al delegado de la sede apostólica sobre el curso de verano que se impartió del 11 julio-19 agosto 1966', in T. Ocampo (comp.), Mexico 'entredicho' del Vaticano al CIDOC, 1966-9: documentos y racciones de prensa (CIDOC dossier xxxvii, $1969), 4 / 2-27$ at $4 / 13$.

${ }_{4}^{8}$ Illich met L. Hoinacki in 1960 in Puerto Rico at the Institute of Intercultural Communication. At the time Hoinacki was a Dominican priest working with Puerto Ricans who wished to emigrate to New York. In 1963 Illich approached the Superior of the Dominicans in Rome to have Hoinacki work in Cuernavaca. After three years in Cuernavaca, Hoinacki decided to abandon the priesthood and get married: R. Whittaker, 'Interview: Lee Hoinacki: conscience and courage', Works $\mathcal{E}^{\circ}$ Conversations (http://www.conversations.org/story.php?sid=5), accessed 11 Nov. 2015 . 49 Ocampo, Mexico 'entredicho' del Vaticano, 4/12. 
surrendering. Those [women religious] who entered without having those experiences, should leave and come back with a better knowledge of what they do ... That all [referring to Sisters] should marry': $5^{1}$ L. Hoinacki

'Female [femenina] religious life could develop, in groups of married people, who meet periodically to have a more intense spiritual life, and a common apostolate. The vow of chastity is not necessary': $5^{2} \mathrm{~V}$. Nazario

'A convent is a mad house, as contrary to nature as is a brothel':53 I. Illich

'The feast of Corpus and the exposure of the Blessed Sacrament will disappear with time for Jesus came to become "nourishment" not to be adored':54 I. Illich

The language of psychoanalysis - evocative of Fromm's interpretation of Freud-seems to be reflected in a preoccupation with psychological needs such as the relief of tension and physical and psychological desires, pleasure and happiness, reason as a tool to establish moral values rather than adhering to authoritarian moral values, emphasis on awareness, and responsibility for one's own action. The latter led to Fromm's rejection of Marxian and Freudian determinism.55 According to Fromm, religion was not superego, an internalisation of an external authority, but its practice was rooted in the ego, life force. $5^{6}$

It is interesting to notice that Gregorio Lemercier pursued a spiritualised psychoanalysis that touched 'the deepest nucleus of the personality; there is no interest in a psychoanalysis that leaves the religious spirit untouched while pretending to analyse all other human traits ... This is evidently an act of faith: faith in the religious spirit, faith in science and faith in faith itself' ${ }^{57}$ Lemercier explained in 1965 that psychoanalysis did not dissolve religion, but transformed it by a process of interiorisation..$^{8}$ Illich did not discuss the benefits of psychoanalysis in the way in which Lemercier or Méndez Arceo did; however, his two seminal documents, 'The seamy side of charity' and 'The vanishing clergyman', need to be read at a psychoanalytical level.

Where is Illich to be placed in these developments? He seems to have assumed the anti-imperialist discourse dominant in the mid-1960s in Latin American leftist circles and among early liberation theologians. He strongly critiqued the notion of progress embraced by the Church. This is clearly conveyed in 'The seamy side of charity'. He wrote that 'Church policy makers in the United States must face up to the socio-political consequences involved in their well-intentioned missionary ventures. They must review their vocation as Christian theologians and their action as

$5^{1}$ Ibid. 4/12. $55^{2}$ Ibid. 4/18. 53 Ibid. 4/21. 54 Ibid. 4/22.

55 Fromm, The heart of man. $\quad 5^{6}$ See idem, Escape from freedom, New York 1941.

57 G. Lemercier, 'A Benedictine monastery and psychoanalysis', CIFR iv (1965), repr. in CIDOC, CIF Reports, IC: January-December I965 (CIDOC Cuaderno, xxxix, $1970), 10 / 24$. $5^{8}$ Lemercier, 'A Benedictine monastery', 19/23-10/24. 
Western politicians.' 59 In his view, theology is used to justify the economic and political capitalist system, its expansion and perpetuation. Psychoanalytic language and the influence of Fromm can be traced in the document. Illich interpreted the lack of vocations as a problem related to corrupted values; the Church and the capitalist system generated an unhealthy system of values that led to alienation and neurosis: 'a healthy sense of values empties the seminaries and the ranks of the clergy much more effectively than a lack of discipline and generosity' ${ }^{60}$ He questioned recruitment practices such as 'hunt[ing] out foreign priests and funds for constructing such anomalies as minor seminaries', ${ }^{61}$ and stressed the need 'to ask ourselves honestly if we need such game'. ${ }^{62}$

Situating himself in the South and in the lived context of Cuernavaca, Illich said that 'exporting Church employees to Latin America masks a universal and unconscious fear of a new Church' which is blind 'to the possibilities of sacralizing person and community'. ${ }^{63} \mathrm{He}$ talked of radical action in strong metaphors: 'Even some doctors prefer aspirins to radical surgery. They feel no guilt having the patient die of cancer, but fear the risk of applying the knife.' ${ }^{4}$ In Illich's experience of forming missioners in Cuernavaca, the 'real' volunteers - here, we find a concern with authenticity and deep interiorisation - wanted to face the truth that would put their faith to the test. It was not a matter of obedience to Superiors. In the introduction to the reissue of 'The seamy side of charity' and 'The vanishing clergyman', Erich Fromm characterises the core of Illich's approach, which certainly varied over time, as humanist radicalism; radicalism refers to an attitude, an 'approach' wherein everything must be doubted, 'particularly the ideological concepts which are virtually shared by everybody and have consequently assumed the role of indubitable commonsensical axioms'. ${ }^{6}$ Radical doubt means to question and is construed as dialectical. It is a process of liberation, of awareness, of a vision of possibilities and options. ${ }^{66}$

'The seamy side of charity' generated strong reactions. America, the Jesuit organ, published it in January 1967. In March the magazine devoted a special section to reactions. This opened with a long letter from the Chilean Renato Poblete sJ, who had taught in Illich's CIC in Cuernavaca. Poblete questioned Illich's statement that the Latin American Church was alienated. Illich had written that 'With the importation of clerics one helps the ecclesiastical bureaucracy survive in its colony. ${ }^{6} 7$ Poblete read that statement as an example of over-generalisation, which he found

59 Illich, 'The seamy side of charity', 88.

6o Ibid. 9o.

61 Ibid.

2 Ibid.

63 Ibid.

64 Ibid.

65 E. Fromm, 'Introduction', to I. Illich, Celebration of awareness, New York 1967, p. vii.

66 Ibid. pp. vii-viii.

67 R. Poblete, 'Religious imperialism in Latin America?', America, 4 Mar. 1967, 317. 
ironic since Illich had made the point again and again that there is no one Latin America. Although acknowledging the need for constant criticism and self-evaluation (which Illich did not limit to methods and institutions, but extended to the ideologies that they embody), Poblete tried to make the case that priests from the USA working in the South were not necessarily agents of companies or the CIA. He grounded his argument in the universal character of a Church which had been built on cultural exchange and movement toward different parts of the world. He said that 'the Church of Latin America received constant influence from different corners of the world. This has enriched, rather than alienated us'. ${ }^{68}$ Poblete's letter did not capture the context of Illich's experience in Cuernavaca and how he positioned his claim in a Latin American configurative space.

There are also central points made by Illich which were not addressed by Poblete. Illich shows a great concern with truth and authenticity in the missionary vocation of ordained and non-ordained missioners. Poblete neglected to consider the strong anti-imperialist stand taken by Illich (not uncommon in Latin America) based on the political relationship between sectors of the Church and American interests in Latin America. Illich wrote that 'The influx of the United States missioners coincides with the Alliance for Progress, Camelot, and CIA projects and looks like a baptism of all three. The Alliance appears directed by Christian justice and is not seen for what it is: a deception designed to maintain the status quo, albeit variously motivated.' ${ }^{69}$ Illich's statements are also in line with social psychoanalysis and the need to unmask institutions, whether they are working for the people or for ideological and economic interests that are not revealed.

The 25 March 1967 issue of America included an article entitled 'What is he getting at?', written by Joseph P. Fitzpatrick sJ, who had worked with Illich in Puerto Rico and had been at Fordham. The article was an explanation of the 'the man and his ideas'. Fitzpatrick opened by saying that in 'The seamy side of charity', Illich bound together 'into one small package all the ideological missiles he has been launching for the past decade'. $7^{\circ}$ After describing Illich's experiences in Puerto Rico and his later work, Fitzpatrick acknowledged that Illich 'has a vision of the radical changes the Church must undergo if it is to be Christ's present to the men of the 21 st century'. ${ }^{11}$ Fitzpatrick grasped Illich's critique of missioners and foreign priests, whose conception of a self-sustaining vigorous Church is founded in the mystique of their country of origin. He wrote:

68 Ibid.

69 Illich, 'The seamy side of charity', go.

$7^{\circ}$ Fitzpatrick, 'What is he getting at?', 444. $7^{1}$ Ibid. 
For years, [Illich] has been pointing to one of the major failures in American apostolic ventures in Latin America, one that desperately needs correcting. He is still pointing to it, but now in a larger context, not only religious but also political and economic. It will be a tragedy if this is brushed off as an expression of his supposed anti-Yanqui sentiments or his lack of charity toward American priests. ${ }^{2}$

'The seamy side of charity' is expressed in the language of the late 196os, which embraced the influence of psychoanalysis, was anti-war (principally the Vietnam War), critiqued the dominance of economic over civil interests and questioned highly bureaucratised forms of public and private management. The latter is evident in the counter-cultural movements of the North in all its variants. The Church is seen by Illich as an extremely bureaucratic organisation.

In line with Illich's previous writings on a new Church and also with 'The vanishing clergyman', 'The seamy side of charity' denounced the potential damage that foreign priests could cause to the Church in Latin America by performing the roles that lay people could take on; this situation would mean that there was "no need to re-examine the structure of the parish, the function of the priest, the Sunday obligation and the clerical sermon; no need to explore the use of the married diaconate, new forms of celebration of the Word and Eucharist, and intimate familial celebrations of conversion to the gospel in the milieu of the home'.73

The sensationalist tone of 'The vanishing clergyman' is set by its first line: 'The Roman Church is the world's largest non-governmental bureaucracy.'74 With short phrases and sharp statements, it condenses the process whereby Illich's thought had been radicalised in relation to the Church as a bureaucratic institution, its structure, full-time celibacy and the future of the ministry as 'ordained lay men' - certainly not women able to earn a living outside the Church. Ordained female and male religious who abandoned celibacy have thereby gone through a process of purification of their faith. In line with Illich's radical humanist approach and familiarity with psychoanalysis, he wrote that when ordained men [sic] understood the sociological, psychological and mythological reasons for celibacy, they recognised its irrelevance to true Christian renunciation.75 The Church, in his view, had two devices for controlling evangelical charisma: the social and juridical organisation of religious communities, and the vows that religious took. Illich retains a concern for the authenticity of the Christian vocation, and maintains that the vow should be a rite testifying authenticity after many years of living a secular life of renunciation. This goes back to statements made by Illich and members of the network

72 Ibid. 445 .

73 Illich, 'The seamy side of charity', 9o.

74 Idem, 'The vanishing clergyman', in Celebration of awareness, New York 1967, 59.

75 Ibid. 76 . 
of centres to religious women and men during the summer course in Mexico City in 1966. Sexuality was an issue that preoccupied Illich and other members of CIDOC and, of course, Lemercier and the Benedictine monks. Psychoanalysis was the tool with which to explore the issue.

Méndez Arceo was very critical of 'The vanishing clergyman', which marked a break in their joint journey in Cuernavaca, although they would continue to be friends. In his view, Illich's critique of the bureaucratic apparatus of the Church became a caricature that ignored the Church's tradition, the supernatural dimension and the human values behind the structures whose disappearance, not renewal, Illich was advocating in the name of the Gospel. 'The vanishing clergyman', Méndez Arceo wrote, could lead to discouragement and disillusion. While acknowledging the need for freedom in research as maintained in Gaudium et Spes, he wrote that 'this freedom has responsibility as counterpart, I must say publically that (leaving aside the content of the article), this publication in Mexico, in the way it was done, it has been a serious error'. ${ }^{6}$

Although it can be argued that, from the start, Ivan Illich had a critical relationship with his Catholic world and the world at large, it is clear that in the case of the papal volunteers and the creation of CIF and CIC, he was not against the papal project, and he was supported financially by the Latin American Bureau of the NCWC. The beginnings of the network of centres were quite conventional in terms of the financial support received from the United States, the relationship with Fordham University and the composition of the CIF board of trustees. Cuernavaca was a creative space within which Illich placed himself, associating himself with the main protagonists of change in the Church and beyond: Méndez Arceo, Erich Fromm and Gregorio Lemercier, among others. Latin America was an ebullient social and political laboratory. Cuernavaca shook Latin America, before Vatican II, with proposals for modernising the Church, liturgical experimentation and the application of social psychoanalysis to religious problems. Alternative visions of the Church and its development came in the South from within various strands of thought, including the development of liberation theology.

In 1964 Illich actually broke with the Board and symbolically with the North, as is clear from the CIF Reports. Illich's writings and the CIF Reports cannot be understood without placing them in this context. A final brief reference to 'The seamy side of charity' and 'The vanishing clergyman': while the first critiqued the Church from an anti-imperialist perspective, the second takes on the bureaucracy of the Church and celibacy. The

$7^{6}$ S. Méndez Arceo, 'Carta del obispo de Cuernavaca a Monseñor Ivan D. Illich', SIEMPRE, 16 July 1967, repr. in López, Fuentes para el estudio de una diócesis, i, 4/10. 
institutional and the personal became embroiled. This was a challenge to Vatican II, which completely neglected issues of sexuality. As might have been expected, Illich did not address women's issues. Attention has been paid in this article to psychoanalysis in Cuernavaca because it helps us to understand what (the 'illocutionary force') lay behind Illich's sometimes aggressive statements and his attacks on celibacy.

Although Illich provided spaces for the discussion of what would become liberation theology, he could not be considered as one of its an exponents. In fact, in this period, his main concern was the institutionalisation of the Church, as a product of modernity, and the dominant ideology of progress, which he attached to modernism. It is in this that he differs from liberation theologians who embraced important Marxist concepts including progress and emancipation. Illich situates himself outside modernism, a force that in his view perverted ancient Christianity, and vindicates pre-modern notions of society and a notion of faith which was not mediated by institutions. Later his position would converge, not surprisingly, with postmodernism.

At the end of 1966, the Revd S. Grabowski, dean of the Institute of Adult Education at the church of Our Lady of Mount Carmel, Bayonne, New Jersey, portrayed the Cuernavaca Centre in this way: 'Even the casual visitor senses in the atmosphere the quiet excitement of a truly Christian revolution of ideas. And that is what Cuernavaca is, a place for the exchange of ideas. Some of the ideas are as old as the Church, some as new as the Second Vatican Council, and some reach out beyond this century.'77

77 S. Grabowski, 'The Center of Intercultural Formation at Cuernavaca', Occasional Bulletin from the Missionary Research Library xvii (1966), 1-5 at p. 1. 